http://revped.ise.ro

\title{
DESIGNING EDUCATION SITUATIONS THAT USE DIGITAL RESOURCES AND ONLINE APPLICATIONS
}

PROIECTAREA SITUAȚIILOR EDUCAȚIONALE CARE UTILIZEAZĂ RESURSE DIGITALE ȘI APLICAȚII ONLINE

\section{Olimpius ISTRATE}

\author{
Journal of Pedagogy, 2018 (2), 45 - 55 \\ https://doi.org/10.26755/RevPed/2018.2/45
}

The online version of this article can be found at: http://revped.ise.ro/category/2018-en/

\section{(C) (i) (2)(2)}

This work is licensed under the Creative Commons Attribution-NonCommercial-ShareAlike 4.0 International License. 94042, USA.

Published by:

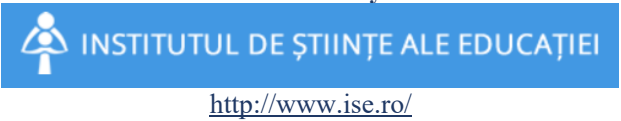

http://www.ise.ro/

Further information about Revista de Pedagogie - Journal of Pedagogy can be found at:

Editorial Policy: http://revped.ise.ro/editorial-policy/

Author Guidelines: http://revped.ise.ro/the-writer-guide-2/ 


\title{
DESIGNING EDUCATION SITUATIONS THAT USE DIGITAL RESOURCES AND ONLINE APPLICATIONS
}

\author{
Olimpius Istrate* \\ University of Bucharest, \\ Faculty of Psychology and Education Sciences, \\ Bucharest, Romania \\ olimpius.istrate@g.unibuc.ro
}

\begin{abstract}
Even if we have educational software, digital resources, online applications, or a virtual learning platform, learning activities planning is not easier or less accurate. Learning and assessment need to be designed even more closely and better tied to learning objectives, to avoid distractors, to fit on the time available, to maximize the potential of digital support to increase the participation of all students, to complement classroom learning with learning activities at home (flipped classroom).

In the context of the "conventional" instructional design, centreed on the calibration of the finalities and methods based on content, theme, audience and available resources, the article presents several models of organising learning originally built to support the design of digital educational games (Quinn, 2005), which can be used to understand how we can transform a didactic activity into an attractive education situation, similar to ludic activities, especially when we can integrate new technologies. We present a selection of three models - mini-scenarios, chained scenarios, conditional scenarios - progressively ordered according to their ability to increase engagement and attractiveness of learning activities.
\end{abstract}

Keywords: Digital educational resources, instructional design, online applications.

\section{Rezumat}

Chiar şi atunci când avem la dispozi ie software educa ional, resurse digitale, aplica ii online sau o platformă educa ională virtuală, planificarea activită ilor de învă are nu este mai simplă sau mai pu in precisă. Activită ile de învă are şi evaluarea trebuie gândite chiar cu mai mare aten ie şi corelate mai bine cu

* Associate Professor, PhD., University of Bucharest, Faculty of Psychology and Education Sciences, Bucharest, Romania. 
obiectivele învă ării, pentru evitarea distractorilor, pentru încadrarea în timp, pentru utilizarea la maxim a poten ialului suportului digital în creşterea participării tuturor elevilor, pentru complementarizarea învă ării din clasă cu activită $i$ de învă are realizate acasă (flipped classroom).

In contextul designului „conven ional” al instruirii, centrat pe calibrarea finalită ilor şi metodelor în func ie de con inuturi, tematică, audien ă şi resurse disponibile, articolul prezintă câteva modele de organizare a activită ilor de învă are, construite ini ial pentru a sus ine designul jocurilor educa ionale digitale (Quinn, 2005), care pot fi utilizate pentru a în elege cum putem transforma o activitate didactică într-un moment atractiv, similar activită ilor ludice, în special în condi iile integrării noilor tehnologii. Prezentăm o selec ie de trei modele mini-scenarii, scenarii înlăn uite, scenarii condi ionate - ordonate progresiv în func ie de capacitatea lor de a creşte angajamentul şi atractivitatea activită ilor de învă are.

Cuvinte-cheie: Aplica ii online, design instruc ional, resurse educa ionale digitale.

\section{Introduction}

Two benchmarks are commonly used to assess the quality of an educator's work, students' performance and participation in the proposed learning activities. Performance (or improvement) is interdependent with participation to a great extent: it is more likely that a good performer is actively involved in activities and it is expected that a student who is attentive and active to learn better. Students' participation in learning activities is not achieved by forcing them to pay attention or by asking them to understand the ultimate goal of learning and the potential value of the information we present (although they also have their role at higher school levels in other). Exclusive use of this tactic in education is counterproductive, leading to the association of school learning with monotony, boredom, frustration, anxiety (Macklem, 2015).

The challenge for teachers is to prepare exciting activities in order to attract students into learning - but it is obvious that, in most cases, one (the same) activity does not meet the interests and needs of all students in a class, nor it is in the zone of proximal development of each of them. That is why we 
can use two ways to optimize teaching activities, which can be combined into practice:

- designing differentiated activities, by group levels, by group of interest, by group of potential (and mixed, where possible);

- designing learning activities that are sufficiently complex for each student to find a (interesting) pathway.

Ensuring optimum learning conditions for class and student is a complex process that cannot be achieved without a plan; most of the times, the "project" is a mental sketch of the sequence of activities to be deployed during a lesson, given the role of each activity, the resources available and the logical chaining of learning contents.

The need to design teaching activities appears as evident in contrast to a preconceived notion that if we give the student access to information we have also provided his/ her learning. There is a major difference between access to information and access to learning, and the role of a teacher is to facilitate learning rather than just providing (access to) information. That is why the teaching has to be multiplied on the way in which the learning will be done, giving beforehand the answer to a series of questions like:

- for whom / with whom do I do the learning activity? where and with what resources do I do it? within what time frame?

- what is the content of learning?

- what is the purpose/ learning objectives for which they do the activity?

- how can I develop the education situation and why do I do it in a certain way and not in another?

- how do I know if and to what extent learning objectives have been achieved?

The new technologies are coming to complete and intensify educational situations, placing themselves in the zone of external conditions for learning. In digital environment, class-group dynamics may be different from how students respond and interact in conventional contexts. Group structure and classroom relationships are partially changed on the basis of the digital competence of each student - often, shy students or students who are not "rated" as being the best can find new learning activities using new technologies, new benchmarks and new ways of expression, more familiar 
and facilitating their school progress. Therefore, teachers can view ICTenabled teaching activities as opportunities to stimulate the progress of certain learners, to bring (some of) them closer to the knowledge domain, and to strengthen class cohesion.

In addition, the time available for the learning unit and the possibility to develop activities in the computer lab, in the school yard, or in the museum is conditioning the choice of methods, assignment of time per each task, the way teachers formulate learning objectives and, implicitly, the assessment ways. A better design of education situations, by using a variety of instructional methods and strategies, by including the tools and resources available at the moment, constitutes the premise for better development of didactic activities, resulting in a better participation of students in activities and higher school performance.

\section{Universal design for learning}

With its roots in neurocognitive science, the concept of "universal design for learning" (UDL) slowly infiltrate in education. Conscious of the unique nature of each student, instead of imposing a solution for all class students, we should offer diverse learning experiences that fit each one, maximizing chances of progress.

The purpose of the universal design is to design a learning activity in order to:

- provide multiple ways of representing the content, mainly referring to the multiplication of the formats in which information is accessible (visual, auditory, kinaesthetic), but also to the degree of difficulty, logical succession or complexity, giving the student the opportunity to choose the way of presentation or the route that suits it more to decode the message;

- provide multiple modes of action and expression: various types of student interaction with the content of learning and alternative possibilities to demonstrate that he/ she has learned;

- provide multiple ways of participation, in order to motivate, support their interest and engage as many students as possible - through interactivity, relevance of proposed scenarios, real life connections, gamification, dynamism. 
Specifically, the universal design proposes to think about activities that really help students in a specific class to go through the learning content we propose:

- always prepare a visual support (cardboard, cards or digital media) for the presentations we do;

- integrate, as much as possible, short relevant videos, educational software, interactive lesson sequences, group exercises etc. - both in what we call 'teaching activity' and in learning and assessment activities;

- vary the didactic strategy and change the approach we use the most often, by conducting more lessons on the inductive strategy, in the lab or in the school yard, dividing students into equal or mixed groups, etc.;

- assess the student not only in "conventional" situations and at the end, by accounting the way he/she works, by appraising various products of the activities (whether digital, online), changing the format of the test, taking into account the assessments of his colleagues or the significance of his contribution in a working group, etc.;

- always keep in mind students' motivation and engagement - if we manage to make them participate voluntarily, we have designed and developed a good lesson.

Universal design is particularly suited to computer-assisted learning, being actually a concept inspired and propelled by the opportunities that new technologies bring to education. Leaving behind the idea of prescribed content, going beyond the times when teaching resources and support materials were scarce, we now have a variety of (complementary) resources - online applications, educational software, digital resources in any field of knowledge, virtual platforms and so on - that we can easily bring into the classroom, offering students the alternative that is closest to them and more plausible in terms of their level, potential and expectations.

\section{Designing participatory and engaging learning}

In almost every sequence, learning can and should be an enjoyable activity for students, rewarding their effort with the satisfaction of succeeding, achieving a stated goal, self-indulgence, participating with colleagues and teachers. The main ingredients are curiosity, play and participation. As regards 
the teacher, designing attractive learning activities supposes availability and openness, student knowledge, pedagogical tools, creativity and much work. To these, another essential component is added: the available instructional resources. Today's teaching material is ubiquitous - activity ideas, learning platforms and information in various formats (text, image, audio, video) can be found on the Internet, at any discipline and at any level of study. There are many studies showing the benefits of using digital resources to increase student motivation and attention, facilitate understanding, increase the relevance of learning content, etc. (Istrate, 2010). At the same time, we must not ignore the value of the conventional activities, for some expected learning outcomes and for some learning content units.

With or without digital resources in learning activities, the design of educational situations is difficult, and the design of quality education situations involves a double effort, in which elements of traditional pedagogy combine with those associated with active participation, often through play, to activities that engage all students (or each student). An explanatory model for the set of instructional design elements that we have to consider make a correlation between the "learning" and the "fun" part (Quinn, 2005), thus building an useful tool for designing participatory educational activities in a ludic form.

Table no. 1. Milestones for participatory and engaging instructional design

\begin{tabular}{l|l|l}
\hline $\begin{array}{c}\text { Learning } \\
\text { conditions }\end{array}$ & $\begin{array}{c}\text { Conditions for } \\
\text { attractive and } \\
\text { engaging activity }\end{array}$ & \multicolumn{1}{|c}{ Synergy, implications, explanations } \\
\hline Contextualisation & Thematic coherence & $\begin{array}{l}\text { 1. Theme: Participatory activity must have a } \\
\text { context, a theme, a "story" - it is possible to use } \\
\text { characters and situations known to all students, } \\
\text { e.g. Wild West, dinosaur age, NASA, trip on the } \\
\text { Moon, group expedition, celebrities in music, } \\
\text { politics, science, etc. Even the feedback needs to } \\
\text { be grafted on the chosen topic, as a dialogue, } \\
\text { appreciation or advice in that context. }\end{array}$ \\
\hline $\begin{array}{l}\text { Precise } \\
\text { objectives }\end{array}$ & $\begin{array}{l}\text { 2. Purpose: The goal must be clear and made } \\
\text { known from the beginning, so that the student } \\
\text { can make informed choices throughout the } \\
\text { course. It is the motivation for action and gives } \\
\text { the measure of progress. Ideally, the goal should } \\
\text { be naturally integrated into the context/ theme of } \\
\text { the activity. }\end{array}$ \\
\hline
\end{tabular}




\begin{tabular}{|c|c|c|}
\hline $\begin{array}{l}\text { Learning } \\
\text { conditions }\end{array}$ & $\begin{array}{c}\text { Conditions for } \\
\text { attractive and } \\
\text { engaging activity }\end{array}$ & Synergy, implications, explanations \\
\hline $\begin{array}{l}\text { Adequate } \\
\text { challenge }\end{array}$ & Balanced challenge & $\begin{array}{l}\text { 3. Challenge: An engaging experience must } \\
\text { have a proper challenge against student's age or } \\
\text { interest horizon, appropriate to the level of } \\
\text { knowledge in the field - it must suit his/ her zone } \\
\text { of proximal development. It should also result in } \\
\text { a succession of balanced and weighted tasks as } \\
\text { level of difficulty (from simple, beginner levels, } \\
\text { to complex, advanced levels) to adequately } \\
\text { accompany student's progress. }\end{array}$ \\
\hline $\begin{array}{l}\text { Anchored in the } \\
\text { study subject }\end{array}$ & $\begin{array}{l}\text { Relevance of action for } \\
\text { the domain }\end{array}$ & $\begin{array}{l}\text { 4. Link between action and disciplinary } \\
\text { content: Situations of the activity scenarios } \\
\text { should require application of knowledge and } \\
\text { exercise of the capacities targeted by the learning } \\
\text { objectives. }\end{array}$ \\
\hline Relevance & $\begin{array}{l}\text { Relevance of the } \\
\text { problem for the learner }\end{array}$ & $\begin{array}{l}\text { 5. Connection between the proposed problem/ } \\
\text { situation and the learner: Another criterion for } \\
\text { the choice of the theme is the connection with the } \\
\text { interests of the student (or of the class group) - he/ she } \\
\text { can react better to certain emotional and motivational } \\
\text { factors, to certain cognitive approaches, to competitive } \\
\text { or collaborative tasks, etc. In addition, if you know } \\
\text { his/her problem-solving style, what preconceived } \\
\text { prejudices or ideas he/she has, you can better } \\
\text { design your activity's tasks, or you can detect } \\
\text { along the way the source of potential mistakes. }\end{array}$ \\
\hline $\begin{array}{l}\text { Open/ free } \\
\text { characteristic. } \\
\text { Possibilities for } \\
\text { exploring further }\end{array}$ & $\begin{array}{l}\text { Choices of the course } \\
\text { of the action }\end{array}$ & $\begin{array}{l}\text { 6. Activism: An effective learning activity offers } \\
\text { possibilities of (cognitive) interaction with the } \\
\text { content of learning and of construction of own } \\
\text { understanding based on this interaction. The } \\
\text { student must be active in making decisions, and } \\
\text { the scenario must contain enough ramifications } \\
\text { to keep him engaged in activity. }\end{array}$ \\
\hline Active handling & Direct handing & $\begin{array}{l}\text { 7. Direct interaction: It is preferable that the } \\
\text { student is able to act (physically) on the } \\
\text { representations of learning contents. In a } \\
\text { conventional situation, for example, it is better to } \\
\text { provide cards with descriptions of options than to } \\
\text { be presented orally. Clicking, scrolling a list, } \\
\text { pressing a key, turning an explanation card, } \\
\text { starting a simulation and stopping it when } \\
\text { needed - these are as well elements of the } \\
\text { unmediated interaction. }\end{array}$ \\
\hline
\end{tabular}




\begin{tabular}{|c|c|c|}
\hline $\begin{array}{l}\text { Learning } \\
\text { conditions }\end{array}$ & $\begin{array}{c}\text { Conditions for } \\
\text { attractive and } \\
\text { engaging activity }\end{array}$ & Synergy, implications, explanations \\
\hline $\begin{array}{l}\text { Appropriate } \\
\text { feedback }\end{array}$ & Association & $\begin{array}{l}\text { 8. Feedback: Any decision has a consequence } \\
\text { with a certain significance for the learning path. } \\
\text { The consequences of the choices must be } \\
\text { presented, preferably embedded in the play/ activity } \\
\text { scenario, on that choice branch, until a new } \\
\text { decision is being made, so that the student builds } \\
\text { his/ her own understanding on the undertaken } \\
\text { sequence. "The story" takes priority - the student } \\
\text { does not have to be "pulled out" from the } \\
\text { scenario, because the activity would lose its } \\
\text { immersive, engaging attribute - a character } \\
\text { (verbal feedback) or a situation in the same } \\
\text { thematic context has to provide feedback. In } \\
\text { complex scenarios, feedback can occur later, } \\
\text { after the student has made other related decisions } \\
\text { that converge to a consequence. }\end{array}$ \\
\hline Gaining attention & $\begin{array}{l}\text { New information and } \\
\text { events }\end{array}$ & $\begin{array}{l}\text { 9. Affect: Each sequence of the scenario must be } \\
\text { unpredictable to the greatest extent possible. } \\
\text { From time to time, the choices can be made "by } \\
\text { chance" by the learner, the information available } \\
\text { for decisions not being complete or sufficiently } \\
\text { structured - therefore the learning path becomes } \\
\text { more interesting, dramatic, de-stressed and at the } \\
\text { same time providing chances to all students to } \\
\text { achieve the didactic goal at the same time. } \\
\text { In addition, especially with respect to digital } \\
\text { materials, special attention is needed to visual } \\
\text { and auditory elements of context: colours used, } \\
\text { fonts, addressing mode, sound effects must not } \\
\text { be distractors, but must be in tune with the } \\
\text { chosen theme and scenario, to strengthen the } \\
\text { message and to contribute to the feeling of } \\
\text { realism. }\end{array}$ \\
\hline
\end{tabular}

Adapted by: Quinn, 2005

We can say that new technologies offer the opportunity to develop a participatory and engaging learning path by creating and joining various types of interactive resources for a learning situation. But the presented model gives us an insight into the key points of how the design of a learning pathway assisted by ICT is effectively being carried out and, not less importantly, suggests how it should NOT be a virtual learning scenario. Various constraints and conditions applicable to "conventional" teaching and learning activities, conducted face-to-face with students, are amplified in the context of computer-assisted education. 


\section{Final considerations}

Integration of ICT tools into teaching brings a number of benefits, including increasing motivation for learning, increased access to information presented in various forms, facilitating understanding, more possibilities for application (direct or mediated) and potential to achieve, to a greater extent, engaging, participative, collaborative learning activities, based on the interest and capacities of each student (Istrate, 2010). However, the experience of the last decades shows that, in practice, the advantages of using new technologies do not have the desired extent, and although intuited, they are not (adequately) aligned with the goals of a ICT-based educational situation (Velea, 2011).

The "new" technologies will become, over time, part of the conditions in which learning takes place in and out of school, surpassing the stage of being novel, surprising and attractive in itself, taking its place of a natural support that favours learning. For the time being, it seems that digital tools and resources contribute to revitalizing the education science and to anchoring it in teaching practice. In instructional design, teachers have to make more often connections with the pedagogical repertoire, due to the fact that, in order to motivate and engage, they integrate into the educational situation a number of elements such as films, educational software, visual media (multimedia) for presentations they hold, virtual labs, virtual visits to museums, etc. (Noveanu \& Istrate, 2005). These must be placed in a (new) pedagogical approach: they must be meaningful in the perspective of the precise role that justifies their use in a particular moment of the lesson, they must be subsumed to a strategy (which they often determine), they must contribute to improving the learning outcomes of the study discipline.

In essence, it is about the pedagogical foundation of the didactic approach, with or without new technologies. An engaging, attractive, motivating learning activity is an activity that has been, above all, well designed. Even more today, in the front of the "native digital" students, a good design of educational situations is an essential condition for a better implementation and development of learning activities, resulting in a wider participation of students to activities and in better school performance. The conceptual platform offered by the "universal design for learning" and the inspiration from the "mechanisms" and routes proposed by the digital applications or games are strengths, 
prerequisites and (already) certainties of a substantive transformation of the education process.

\section{References}

- Davis, N., Desforg,C., Jessel J., Somekh, B., Taylor, C., \& Vaughan, G. (1996). Can quality in learning be enhances through the use of IT?. In: B. Somekh \& N. Davis (coord.). Using Information Technology Effectively in Teaching and Learning: Studies in Pre-service and In-service Teacher Education. London: Routledge, 1996.

- Dede, C. (2010). Emerging influences of information technology on school curriculum. Journal of Curriculum Studies, 32(2), 281-303. https://doi.org/ $10.1080 / 002202700182763$.

- Eagleton, M. (2008). Universal Design for Learning. EBSCO Research Starters: EBSCO Publishing Inc. Online. Retreived from https://www.ebscohost.com/ uploads/imported/thisTopic-dbTopic-1073.pdf.

- Gagné, R.M., \& Briggs, L.J. (1977). Principii de design al instruirii. Bucharest: E.D.P.

- Istrate, O. (2010). Efecte şi rezultate ale integrării TIC în educa ie. Conferin a Na ională de Învă ământ Virtual, edi ia a VIII-a (National Conference on Virtual Education, $8^{\text {th }}$ edition), CNIV 2010. University of Bucharest. Retrieved from: https://www.academia.edu/3356979/.

- Jinga, I., \& Negre-Dobridor, I. (2004). Inspec ia şcolară şi design-ul instruc ional. Bucharest: Aramis Print.

- Lindstrom, C., \& Drolet, B.M. (2017). What Is Universal Design for Learning?What's Missing? Best Practices for Teaching Students with Disabilities. Lanham: Rowman \& Littlefield.

- Macklem, G.L. (2015). Boredom in the classroom: Addressing student motivation, self-regulation, and engagement in learning. Springer International Publishing. https://doi.org/10.1007/978-3-319-13120-7.

- Meyer, A., \& Rose, D. H. (1998). Learning to read in the computer age. Cambridge, MA: Brookline.

- Noveanu, E., \& Istrate, O. (2005). Impactul formativ al utilizării AEL în educa ie. Raport de cercetare. Bucharest: TEHNE - Centrul pentru Dezvoltare şi Inovare în Educa ie. Retrieved from: http://www.tehne.ro/resurse/TEHNE_Impact_formativ_ AEL_2005.pdf.

- Quinn, C.N. (2005). Engaging Learning. Designing e-Learning Simulation Games. San Francisco: Pfeiffer.

- Rudd, P. (2000). School Improvement through ICT: Limitations and 
Possibilities.Proceedings of the European Conference on Educational Research (ECER). Retrieved from: http://www.leeds.ac.uk/educol/documents/ 00001768.htm.

- Tardy, M. (1993). La transpozition didactique. J. Houssaye (Ed.), La pédagogie: une encyclopédie pour aujourd'hui. Paris: E.S.F.

- UDL Center/ CAST. Principii de Design Universal pentru Instruire. Retrieved from (May 2017): http://www.udlcenter.org/sites/udlcenter.org/files/ UDL_Guidelines_v1.0-RO.pdf.

- Velea, S. (2011) ICT in education: responsible use or a fashionable practice. The impact of eTwinning action on the education process.M. Vlada (ed.) ICVL. Proceedings of the 6th International Conference on Virtual Learning. Bucharest: University of Bucharest Publishing House.

The online version of this article can be found at: http://revped.ise.ro/category/2018-en/

\section{(cc) $\mathrm{Br}-\mathrm{Ne}-\mathrm{SA}$}

This work is licensed under the Creative Commons Attribution-NonCommercial-ShareAlike 4.0 International License.

To view a copy of this license, visithttp://creativecommons.org/licenses/by-ncsa/4.0/ or send a letter to Creative Commons, $P O$ Box 1866, Mountain View, CA 94042, USA.
Versiunea online a acestui articol poate fi găsită la:http://revped.ise.ro/category/2018-ro/

\section{(cc) DY-Ne-sA}

Această lucrare este licen iată sub Creative Commons Attribution-NonCommercial-ShareAlike 4.0 International License.

Pentru a vedea o copie a acestei licen e, vizita $i$ http://creativecommons.org/licenses/by-nc-sa/4.0/ sau trimite i o scrisoare către Creative Commons, PO Box 1866, Mountain View, CA 94042, SUA. 